WMJ (Warmadewa Medical Journal), Vol. 5 No. 1 Mei 2020, Hal. 1-7

\title{
Case Report: Exercise-Induced Supraventricular Tachycardia in a 16-Year-Old Boy with Tricuspid Regurgitation
}

\author{
Putu Satya Pratiwi ${ }^{1}$, Romy Windiyanto ${ }^{2}$, I Gede Bagus Gita Pranata Putra ${ }^{3}$ \\ ${ }^{I}$ RSUD Sanjiwani, Gianyar \\ ${ }^{2}$ Departemen Ilmu Kesehatan Anak, RSUD Sanjiwani, Gianyar \\ ${ }^{3}$ Departemen Ilmu Penyakit Dalam, RSUD Sanjiwani, Gianyar \\ E-mail': pratiwisatya@gmail.com
}

\begin{abstract}
Supraventricular tachycardia (SVT) is a tachydysrhythmia that is often found in pediatric patients which requires treatment. In contrast to sinus tachycardia, SVT is not a normal compensatory response to physiological stress. This article discusses the case of supraventricular tachycardia in a 16-year-old boy, which appear during strenuous exercise. In this case a guide was also provided in identifying SVT, excluding the differential diagnosis for narrow complex tachycardia, followed by guidelines for the management of pediatric tachycardia based on the Pediatric Advanced Life Support algorithm.
\end{abstract}

Keywords: tachycardia, supraventricular tachycardia, AVNRT.

\section{Abstrak}

[Laporan Kasus: Takikardia Supraventrikular Pasca-olahraga pada Anak Laki-laki Usia 16 Tahun dengan Regurgitasi Trikuspid]

Takikardia supraventrikular (SVT) adalah takidisritmia yang sering ditemukan pada pasien anak yang membutuhkan pengobatan. Berbeda dengan takikardia sinus, SVT bukan merupakan respon kompensatorik normal terhadap stres fisiologis. Artikel ini membahas tentang kasus takikardi supraventrikel pada anak lakilaki berusia 16 tahun yang muncul ketika berolahraga berat. Dalam kasus ini turut disajikan panduan dalam mengidentifikasi gambaran SVT, mengesklusi diagnosis banding untuk takikardia kompleks sempit, diikuti dengan panduan untuk tatalaksana takikardia pediatrik berdasarkan algoritme Pediatric Advanced Life Support.

Kata Kunci: takikardia, takikardi supraventrikel, AVNRT

\section{INTRODUCTION}

Supraventricular tachycardia (SVT) is an abnormally fast heart rhythm in the upper part of the heart which frequently found in pediatric patients. The incidence of SVT is about 1 in 250 to 1 in 1000 children. ${ }^{1,2}$ Most of SVT cases in pediatrics ( $>90 \%)$ is caused by either extranodal accessory pathways (Atrioventricular reentrant tachycardia, including Wolff-Parkinson-White syndrome) or reentrant circuit through atrioventricular nodal (atrioventricular nodal reentrant tachycardia). ${ }^{3}$

Supraventricular tachycardia is the most frequent tachydysrhythmia in pediatric patients requiring medical treatment. In contrast to sinus tachycardia, SVT is not a normal compensatory response to physiologic stress. Although most of SVT patients identified as mild, some patients may develop heart failure and cardiogenic shock if underdiagnosed. This case report will discuss a vigorous exercise - induced supraventricular tachycardia case of a 16 yearold boy. ${ }^{2,4}$

\section{CASE REPORT}

A 16 year-old boy was admitted to Emergency Department because he experienced fast heartbeat since 2 days prior his hospital admission. The fast heart rhythm was firstly noticed 30 minutes after he did running exercise, and the symptom continued until he was sent to Emergency Room. The rapid heart rate was felt on the left 
chest. It was said that the rapid heart rate did not disappear even though the patients was on rest. The exercise intensity was very heavy thus the patient was about to pass out. The patients denied to have had similar experience beforehand. There was no other factors worsen the symptom. History of consuming energy drink, coffee, as well as smoking was denied. Patient did not administer any medication to relieve the symptom. Beside the fast heartbeat, patients also claimed to feel nausea and vomiting.

During physical examination in Emergency room, the consciousness was compos mentis, blood pressure was 100/60 $\mathrm{mmHg}$, pulse was 170 beats/minute, respiratory rate was 24 breaths/minutes, $\mathrm{O}_{2}$ saturation was $100 \%$ on room air, and body temperature was $36^{\circ} \mathrm{C}$. Body weight was 55 $\mathrm{kg}$, height was $160 \mathrm{~cm}$. General physical examination showed no abnormalities; chest physical examination showed first and second heart sound to be single, without murmur, sound of the ventricular respiratory was heard on both lungs. There was no enlargement on palpasi of thyroid gland. The fourth superior extremities was warm

Additional medical examination such as electrocardiograph (ECG), thorax photo roentgen, blood tests, random blood sugar test, electrolyte measurement, TSH and FT4 were also conducted. ECG in monitor showed supraventricular tachycardia. Complete blood tests showed leukocytosis with WBC count of $12.81 \times 103 / \mathrm{uL}$, increased neutrophile $(8.72 \times 103 / \mathrm{uL})$, hemoglobin $(14.3 \mathrm{~g} / \mathrm{dL})$, and thrombocyte (227 x 103/ $\mathrm{uL})$. The random blood sugar level was slightly increased (134 mg/dL) and electrolyte examinations (sodium, potassium, and chloride) were in normal range. The examination of FT4 (14.15 mmol/L) and TSH (0.608 IU/mL) were normal.

As the initial treatment in emergency room, patient was given oxygen with flow rate of 2 liters per minute through nasal cannula and was given 20 drops per minute of D5 $1 / 2$ normal saline infusion. Vagal maneuver was carried out by putting icepack on patient's face and applying carotid sinus massage for 20 seconds while keep observing the blood pressure, pulse, and ECG. Since the rhythm was not converted into sinus, the next medical treatment guideline was administering $5 \mathrm{mg} / \mathrm{kg} \mathrm{BW}$ parenteral amiodarone $\sim 275 \mathrm{mg}$ loading, over 20 minutes. Few minutes after amiodarone infusion, ECG showed prolonged of QT interval. Amiodarone administration was continued with maintaining dose of $15 \mathrm{mg} /$ $\mathrm{kg} \mathrm{BW}$, prepared by dilution of $825 \mathrm{mg}$ in $50 \mathrm{~mL}$ of $5 \%$ dextrose; flow rate was 5 $\mathrm{mcg} / \mathrm{kg} / \mathrm{minute}$. The patient was also given $2.5 \mathrm{mg}$ oral bisoprolol every 24 hours. ECG examination was done every 6 hours and patient were under observation in PICU room.

On second day of treatment, ECG showed sinus rhythm, there was no fast heart beat complain. ECG examination showed result of mild tricuspid regurgitation with ejection fraction of 59\%. Patient was sent to tertiary referral hospital to get further examination and treatment by pediatric cardiologist because there was no pediatric cardiologist in our hospital.

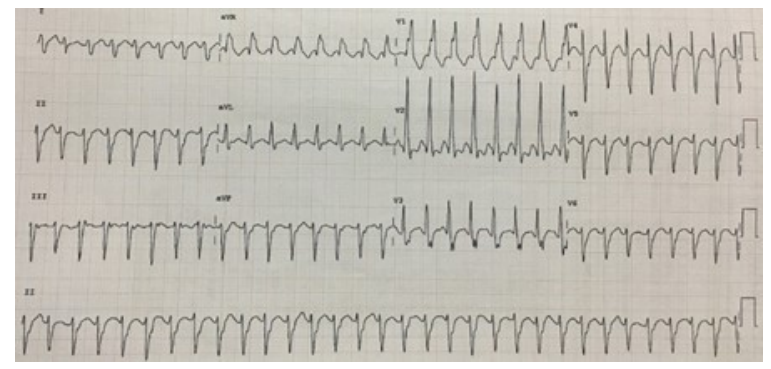

Figure 1 ECG record shows supraventricular tachycardia rhythm. QRS complex appears to be widen.

$\mathrm{R}-\mathrm{P}$ appears to be shorter than P-R, AVNRT is typical

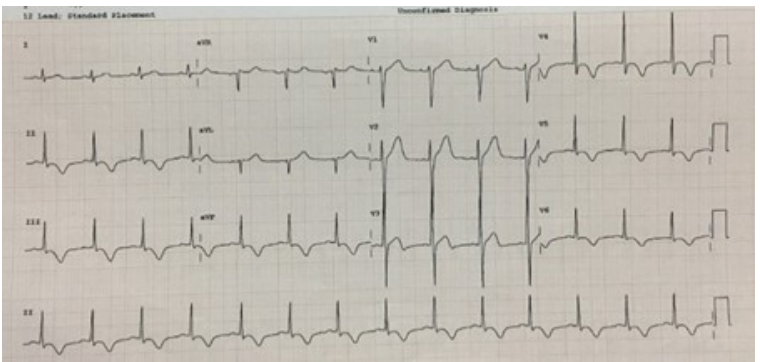

Figure 2 After amiodarone administration, prolonged QTC interval $>488 \mathrm{mS}$, the waves are clear 
with rhythm rate of 85 times per minute. $\mathrm{T}$ inversion in leads II, III, aVF, and leads V4-6.

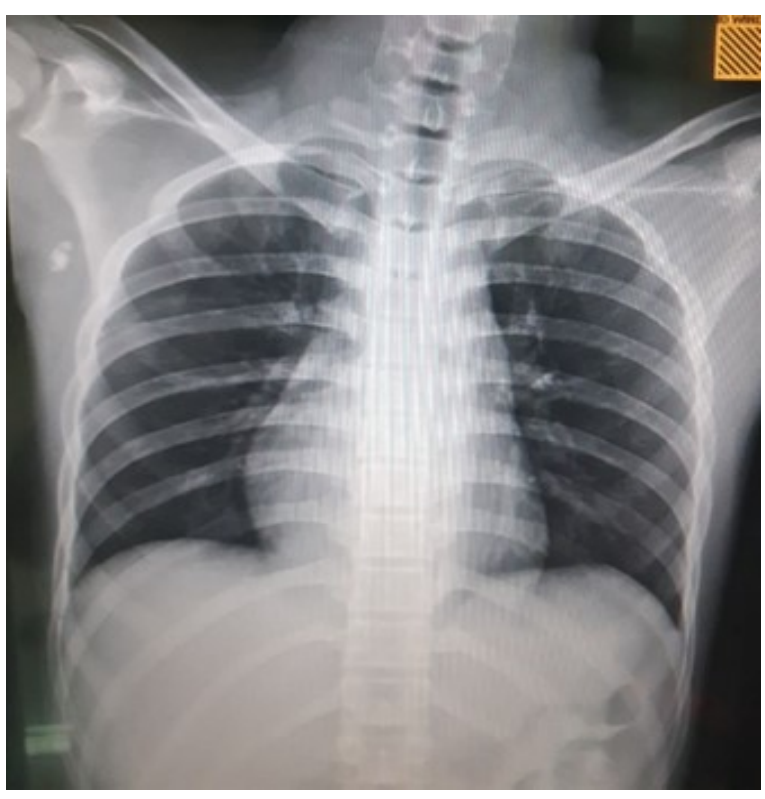

Figure 3 Thorax photo shows no cardiomegaly, with CTR of $49 \%$. Foto polos thoraks menunjukkan tidak adanya kardiomegali, dengan CTR 49\%. Cardiac waist seems disappear.
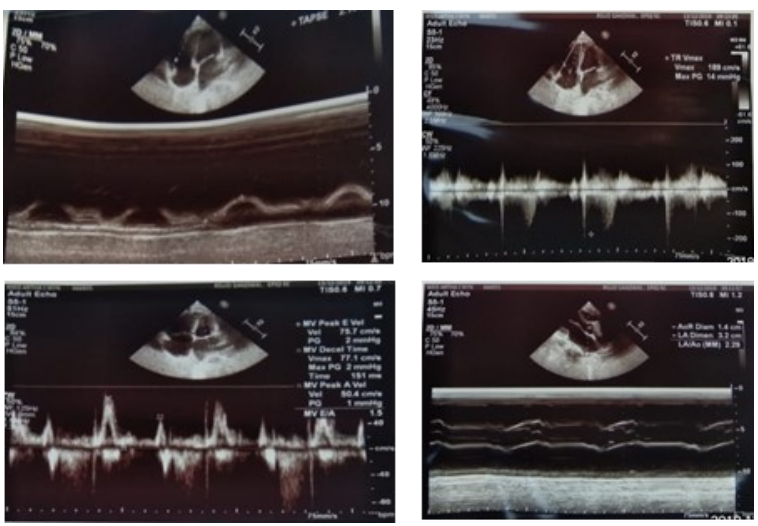

Figure 4 ECG examination shows mild tricuspid regurgitation with $59 \%$ ejection fraction.

\section{DISCUSSION}

In this case, the patient complained of having fast heart rate which appeared during exercise and remained without improvement even after taking rest. The ECG monitor showed pulse 183 beat per minute, with visible $\mathrm{P}$ wave and narrow QRS complex. In SVT case, heart rate usually exceeds 220 beat per minute in babies or 180 beat per minute in children. The onset of this rhythm occurred abruptly. ECG shows regular rhythm with narrow QRS complex (0.09 second or less) which continual as response to activity or stimulus. 1,3

The distinction between sinus tachycardia and supraventricular tachycardia is explained in Table 1. ${ }^{1}$ Based on differential diagnostic algorithm for narrow complex tachycardia (figure 4), with visible $\mathrm{P}$ wave and shorter R-P interval compared to P-R interval indicates typical AV nodal reentrant tachycardia (AVNRT). As the first premature impulse travels through slow pathways into antegrade, which shown by prolonged PR interval during initial beat of tachycardia. During reentry, there is simultaneous activation of atrium and ventricles. Thus, P wave and QRS complex occur almost simultaneous and invoke tachycardia without RP or very short RP. The P wave will appear negative in leads II, III and aVF as impulse travels retrograde from lower atrium to higher atrium. The $\mathrm{P}$ wave also has smaller widht which indicates septum activation. ${ }^{5}$

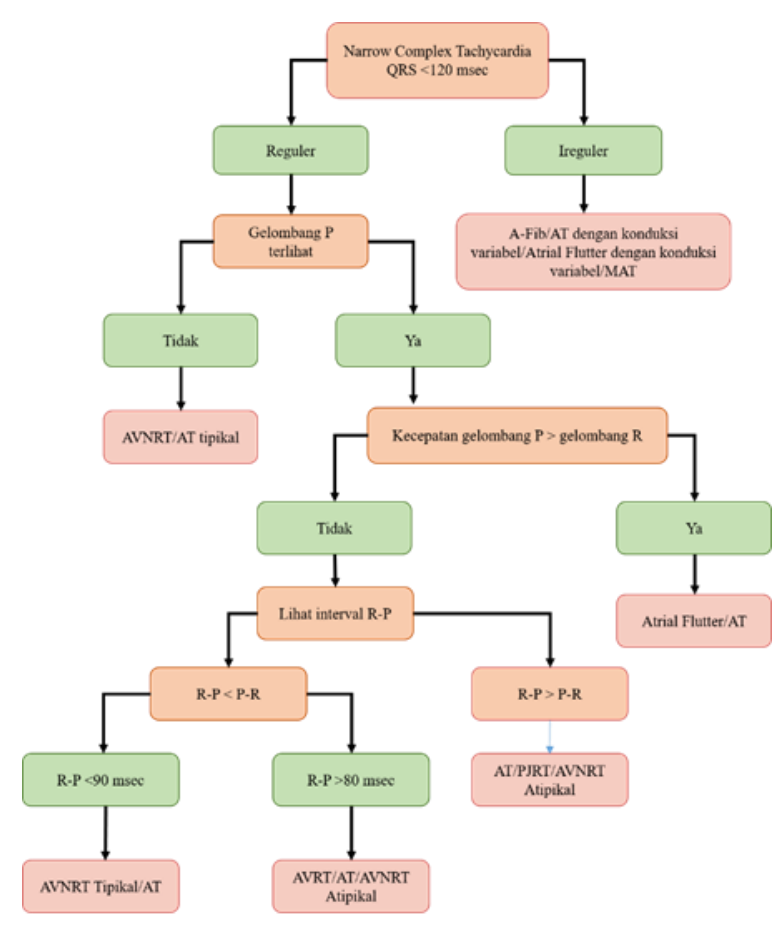

Figure 4 Differential diagnostic algorithm of narrow complex tachycardia. A-Fib, atrial fibrillation;

PJRT, permanent junctional reciprocating tachycardia. $^{5}$ 
The patient did not have any disease history neither any significant physical examination. Considered differential diagnosis were electrolyte abnormalities, hyperthyroidism, and/or medication side effect (digoxin, pseudoephedrine, alcohol). The increased of physiological demands (exercise, stress, and others) caused accelerated heartbeat. In normal situation, impulse travels anterograde from sinoatrial nodes to ventricle through atrioventricular nodes which plays role on keeping the contraction sync between atrium and ventricles. The signal movement depends on electrical homogeneity of surrounding conduction path, indicated by refractory period and the same conduction. When two separate paths have different refractory velocity and conduction, reentry circuit is formed. ${ }^{5,6}$

Table 1. Differences between sinus tachycardia and supraventricular tachycardia ${ }^{1}$

\begin{tabular}{|l|l|l|}
\hline Characteristics & \multicolumn{1}{|c|}{ Sinus Tachycardia } & \multicolumn{1}{|c|}{ Supraventricular Tachycardia } \\
\hline Rate & $\begin{array}{l}\text { Usually less than 220 beat per mi- } \\
\text { nute in babies and less 180 beat per } \\
\text { minute in children }\end{array}$ & $\begin{array}{l}\text { Usually 220 beat per minute or more } \\
\text { in babies and 180 beat per minute or } \\
\text { more in children }\end{array}$ \\
\hline $\begin{array}{l}\text { Rate and regularity } \\
\text { of ventricle }\end{array}$ & $\begin{array}{l}\text { Varied depends on activity/ } \\
\text { stimulation }\end{array}$ & Constant with activity/stimulus \\
\hline Onset and & Gradual & Abrupt \\
\hline the end of P wave & Visible, normal & $\begin{array}{l}\text { Sometimes is not seen, if it seen, it } \\
\text { will look different compared to P } \\
\text { wave of SA node }\end{array}$ \\
\hline Medical History & $\begin{array}{l}\text { Anamnesis explains the cause of in- } \\
\text { creased HR, pain, fever, loss of liq- } \\
\text { uid or blood due to trauma, vomiting, } \\
\text { or diarrhea. }\end{array}$ & $\begin{array}{l}\text { In the absent of congenital heart dis- } \\
\text { eases, history is usually non-specific } \\
\text { (e.g. medical history does not explain } \\
\text { the increased HR); meanwhile, baby } \\
\text { usually comes with complains such as } \\
\text { refused to eat, behaving not as usu- } \\
\text { al', sweating during meal, or more } \\
\text { fussy. }\end{array}$ \\
\hline $\begin{array}{l}\text { Physical Exami- } \\
\text { nation }\end{array}$ & $\begin{array}{l}\text { Consistent with volume loss (blood, } \\
\text { diarrhea, vomiting), might have fe- } \\
\text { ver, clean lungs, normal liver size }\end{array}$ & $\begin{array}{l}\text { Bad perfusion sign, including de- } \\
\text { creased peripheral pulse, decreased } \\
\text { capillary refill, pale, increased breath- } \\
\text { ing effort, crackle, liver enlargement }\end{array}$ \\
\hline
\end{tabular}

Vagal maneuver was conducted to this patient by putting icepack on his face, and then continued with carotid massage for 20 seconds. ${ }^{1}$ Vagal maneuver is the first line therapy for regular SVT patients with stabile hemodynamic. Valsalva maneuver is the most effective technique, followed by carotid massage (for adults) and immersing face into cold water (for children). Intravenous adenosine is an effective and fast therapy for SVT in acute situation, as described in pediatric tachycardia algorithm (figure 5). ${ }^{3,6}$ 


\section{WMJ (Warmadewa Medical Journal), Vol. 5 No. 1, Mei 2020, Hal. 5}

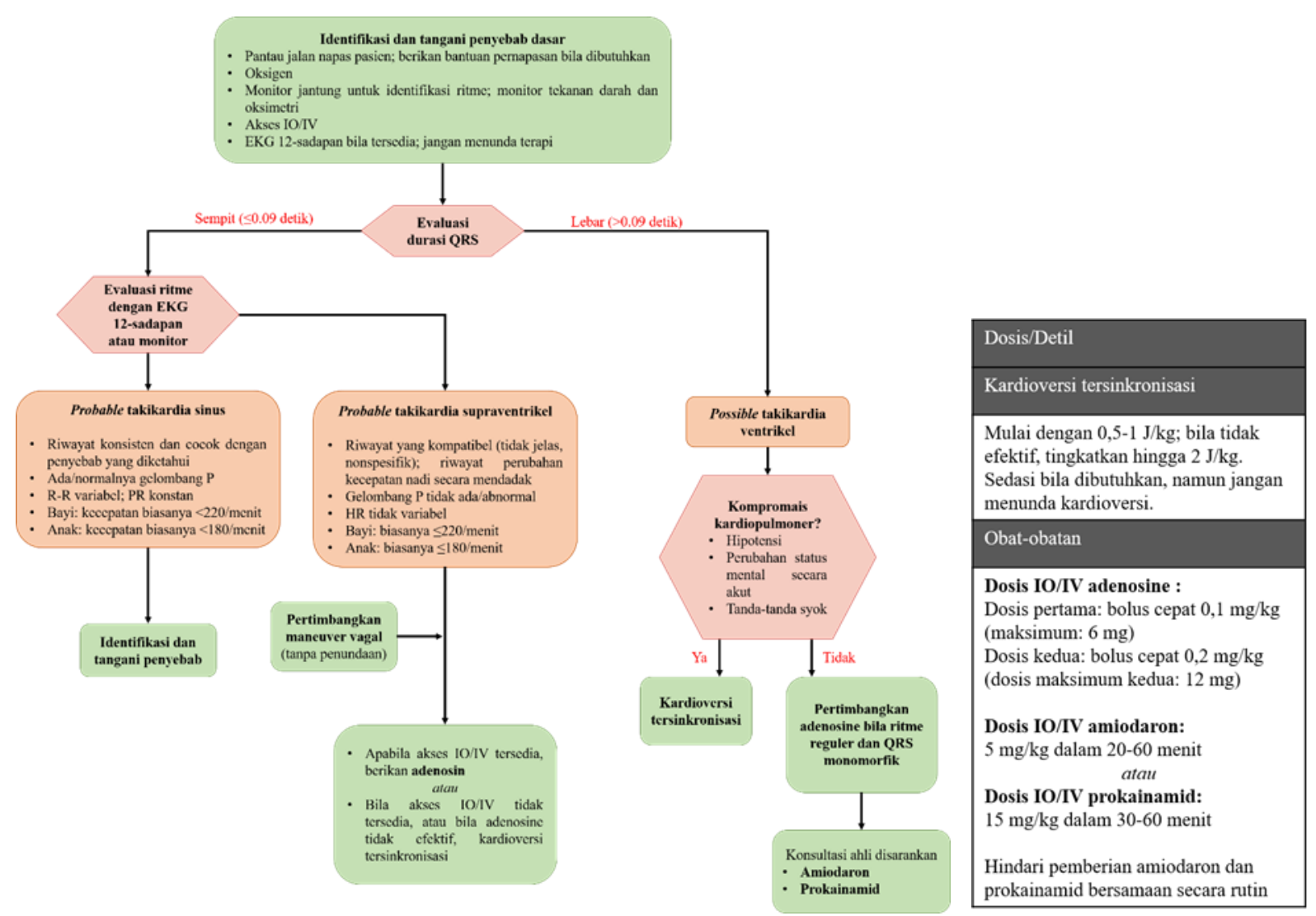

Figure 5 Pediatric tachycardia algorithm with poor pulse and perfusion ${ }^{1}$

Adenosine is a recommended abortive therapy based on Pediatric Advanced Life Support; it is used as first line therapy for all type of SVT, except for atrial flutter. Because adenosine was not available, amiodarone, the second line therapy, was given with loading dose of $5 \mathrm{mg} / \mathrm{BW}$ over 20 minutes, followed by maintaining dose. Amiodarone is a class III anti-arrhythmic which works by blocking potassium channel and prolongs the repolarization. ${ }^{1,7}$

Few minutes after administration of amiodarone, ECG result showed prolonged QT interval. Torsade de Pointes (TdP) has been associated with medication including astemizole, cisapride, pentamidine, risperidone, antiarrhythmic agents (amiodarone, procainamide, and sotalol) and antifungal (fluconazole and voriconazole). In adults, risk factors for QTc interval prolongation includes being female, elderly ( $>65$ years old), hypokalemia, hypomagnesemia, or hipocalcemia, heart failure with reduced ejection fraction, polypharmacy-induced prolonged QT interval, and conditions that causes the increased of plasma concentration of certain medications such as kidney and liver diseases. ${ }^{8}$

As for now, the risk factors accounted for pediatric population has not been known. However, being female is not risk factor for prolonged QTc interval in children as both girls and boys have the same QTc until their onset of puberty. ${ }^{8}$

In this case, echocardiography examination was conducted to evaluate whether there was congenital heart abnormalities that potentially caused the SVT. Echocardiography examination showed mild tricuspid regurgitation (TR), with $59 \%$ ejection fraction. TR could occurred in $65-85 \%$ of population, thus the mild TR found in normal tricuspid valve was deemed as normal variation..$^{9}$ According to study by L'Italien (2018), older children or teenagers without existing heart disease, who come down 
with SVT without ventricular preexcitation, echocardiography might not the initial evaluation needed when physical examination and electrocardiography shows normal result. $^{10}$

Amiodarone is a class III of antiarrhythmic agents which mainly works as potassium channel blocker and responsible for repolarization of heart during phase 3 of potential action. The effect of the blockage caused prolonged duration of potential action and prolongs the effective refractory period on cardiac myocyte. Myocyte excitability is reduced, prevent reentry mechanism and ectopic focus to proceed with the tachyarrhythmia. Evidence of the electrocardiography effect showed by prolongation of QRS duration and QT interval. ${ }^{11,12}$

Unlike the other class III agents, amiodarone also interacts with $\beta$-adrenergic receptor, potassium channel, and sodium channel. Further electrophysiology manifestations of this agent include reduced automation of sinoatrial node (SA) and conduction velocity of AV node, and inhibits ectopic pacemaker automation. In some cases, these additional action mechanisms cause adverse effects, including bradycardia, hypotension, and Torsade de pointes (TdP).

Bisoprolol is a selective $\beta 1$ adrenergic receptor inhibitor, classified as class II antiarrhythmic agents, IIa subclass. Beta-adrenergic blockage agent is effective treatment for patient with supraventricular tachycardia, because its capacity to prevent $\beta$-adrenergic stimulation effect on tissue of sinus node and atrioventricular. Beta blocker suppresses automation of sinus node and inhibits atrioventricular node function by prolongation of refractory and slowing down the conduction. Supraventricular arrhythmia which is dependent to this structure, either to continue or to conduct to ventricle, is thought to be sensitive to beta blockage. $^{12,13}$

Nondihydropyridine calcium channel blocker (verapamil, diltiazem) and beta blocker (metoprolol) give longer blockage effect to AV node compared to adenosine, and they can be given in acute situation. Verapamil has equal effectivity, more frequently causes hypotension, while adenosine can cause more frequent minor adverse effects. When one of them is not effective, they can be substitute with each other. $^{\text {? }}$

\section{CONCLUSIONS}

We have presented a case of supraventricular tachycardia of a 16-year old boy, who complained of having fast heart rate for two days post vigorous exercise. According to electrocardiography examination, it was found to be narrow complex tachycardia with visible $\mathrm{P}$ wave, shorter R$\mathrm{P}$ interval compared to P-R interval indicating typical AV nodal reentrant tachycardia (AVNRT). Differential diagnosis includes hyperthyroid, electrolyte imbalances were eliminated by laboratory tests. Abortive therapy in the form of vagal maneuver was conducted and proceeded with intravenous administration of amiodarone as the vagal maneuver failed. Echocardiography examination was carried out after the rhythm return to sinus and the result was tricuspid regurgitation. Antiarrhythmic agent, bisoprolol, was given during the inpatient hospital stay, and the patient was discharged after two day treatment with absent of complain. Patient was referred to pediatric cardiologist in tertiary hospital.

\section{REFERENCES}

1. Aehlert B. Pediatric advanced life support study. Burlington: Joness \& Bartlett Learning; 2017.

2. Chu PY, Hill KD, Clark RH, Smith PB, Hornik CP. Treatment of supraventricular tachycardia in infants: analysis of a large multicenter database. Early Hum Dev. 2015;91 (6):345-50.

3. Richardson C, Silver ES. Management of supraventricular tachycardia in infants. Pediatr Drugs. 2017.

4. Dadi G, Fink D, Weiser G. High- 
dose adenosin for refractory supraventricular tachycardia: a case report and literature review. Cardiology in the young. 2016.

5. Mahtani AU, Nair DG. Supraventricular tachycardia. Med Clin N Am. 2019;103(5):863-79.

6. Al-Zaiti SS, Magdic KS. Paroxysmal supraventricular tachycardia: pathophysiology, diagnosis and management. Crit Care Nurs Clin N Am. 2016.

7. Helton MR. Diagnosis and management of common types of supraventricular tachycardia. Am Fam Physician. 2015 Nov 1;92(9):793802.

8. Tisdale JE. Drug-induced QT interval prolongation in children: are the kids alright? CJHP. 2016;69(3):183-4.

9. Arsalan M, Walther T, Il RLS, Grayburn PA. Tricuspid regurgitation diagnosis and treatment. European
Heart Journal. 2015.

10. L'Italien K, Conlon S, Kertesz N, Bezold L, Kamp A. Usefulness of Echocardiography in Children with NewOnset Supraventricular Tachycardia. Journal of the American Society of Echocardiography. 2018;31(10):1146 -1150 .

11. Florek JB, Girzadas D. Amiodarone. [Updated 2019 Oct 12]. In: StatPearls [Internet]. Treasure Island (FL): StatPearls Publishing; 2019 Jan. Available from: https:// www.ncbi.nlm.nih.gov/books/ NBK482154/

12. Lei M, Wu L, Terrar DA, Huang CLH. Modernized classification of cardiac antiarrhythmic drugs. Circulation. 2018;138:1879-1896.

13. Kowey PR, Friehling TD, Marinchak RA. Electrophysiology of beta blockers in supraventricular arrhythmias. Am J Cardiol 1987;60:32D-38D. 